\title{
The relationships between selected soil properties and caesium-137 identify organic carbon, nitrogen and water soluble phenols as indicators of soil erosion processes in different forest stands
}

\author{
Federico Romeo $^{1} \cdot$ Paolo Porto $^{1} \cdot$ Carmelo Mallamaci $^{1}$. \\ Adele Muscolo ${ }^{1}$
}

Received: 4 November 2020 / Accepted: 10 December 2020 / Published online: 12 February 2021

(C) The Author(s) 2021

\begin{abstract}
In the last few decades, the use of environmental radionuclides, particularly caesium- $137\left({ }^{137} \mathrm{Cs}\right)$, represented one of the most valid methods for estimating soil erosion. However, the cost associated with the use of the equipment needed for radiometric analyses is still high and, for this reason, finding more easily measurable indicators can be useful. There is a strong correlation between ${ }^{137} \mathrm{Cs}$, organic carbon $(\mathrm{OC})$, nitrogen $(\mathrm{N})$ and water soluble phenols (WSP) exists, indicating the latter parameters as possible early indicators of soil erosion. Based on the above assumptions, the main purpose of this work is to identify specific soil chemical parameters able to indicate early triggering of soil erosion. Specifically, several soil parameters such as $\mathrm{pH}$, electric conductivity (EC), WSP, OC, $\mathrm{N}$ and $\mathrm{C} / \mathrm{N}$ have been evaluated against ${ }^{137} \mathrm{Cs}$ and on a comparative basis. In addition, since the rate of soil erosion depends on the degree of coverage and canopy structure, two different tree species (Pinus nigra laricio Poir. and Fagus sylvatica L.) have been considered in this contribution in which ten different scenarios of forest management have been analysed. The results show that the reduction in tree cover of managed sites triggers erosion and nutrient loss processes. It has been observed that the loss of ${ }^{137} \mathrm{Cs}$, compared to the control areas, is closely correlated
\end{abstract}

Project funding: The study was supported by the Coordinated Research Project (CRP) D1.50.17 within the framework of the International Atomic Energy Agency (IAEA).

The online version is available at http://www.springerlink.com.

Corresponding editor: Yu Lei.

Adele Muscolo

amuscolo@unirc.it

1 Department of Agriculture, Mediterranea University, Feo di Vito, 89122 Reggio Calabria, Italy with those of WSP, OC and N. These parameters (WSP, OC and $\mathrm{N}$ ), more easily assessable, can be a valid tool to understand easily, triggering of erosive phenomena.

Keywords ${ }^{137} \mathrm{Cs} \cdot$ Erosion indicators $\cdot$ Forest thinning · Beech forest $\cdot$ Pine forest

\section{Introduction}

Soil erosion/degradation depends on many factors such as soil characteristics, ground slope, vegetation cover and distribution, as well as amount and intensity of rain, which in turn can severely affect soil quality and productivity by removing the most fertile topsoil (Zuazo and Pleguezuelo 2008). Soil erosion depends also by anthropic interventions both in agriculture than in forest fields. Considering the key role played by soil in view of the planet's sustainable future, and taking into account that soil is lost from terrestrial areas from 10 to 40 times faster than its renewal, imperilling food security and environmental quality (FAO 2017), it is of primary importance, nowadays, to individuate, as soon as possible, the triggering of soil erosion process.

Forests play a pivotal role in maintaining the environmental ecological balance, and are strictly connected with soils with a great influence on each other and on the wider environment. Nowadays, the growing population growth and the consequent request for timber and fibres, in addition to the growing global market concurrence are exacerbating the pressure on forest ecosystems. All this is leading to an intensification of forest management activities, which if improperly executed can result in serious damages to soil, with organic matter loss, nutrient cycle disequilibrium (Johnson 1992; Neary et al. 1999; Balboa-Murias et al. 2006; Nilsen and Strand 2008), and soil compaction. 
Thus, appropriate forest management practices, to maintain or improve forest cover on erosion-incline soils, could help to control or reduce soil erosion processes.

Considering that the effects of anthropogenic forest interventions are not visible on soil in a short time, there is now the increasing exigency of individuating techniques easy and cheap to detect the effect of silvicultural practices on soil properties. In the past, various attempts tried to early individuate erosive phenomena, primarily based on models and calculation procedures that required detailed information about soil and plant characteristics, climate, topography and human impact (Morgan et al. 1992; Renard and Freimund 1994; De Roo et al. 1996). However, these methods require several physical assumptions and remain confined to geographical zones where calibration and validation are possible. Since the early eighties, the use of environmental radionuclides particularly caesium-137 $\left({ }^{137} \mathrm{Cs}\right)$, represented one of the most valid methods for estimating soil erosion. This technique based on the general assumption that, following bombing fallout or nuclear accidents, ${ }^{137} \mathrm{Cs}$ reaching the earth's surface, was quickly and intensely absorbed by soil surface and redistributed into the landscape with the erosion, transport and deposition of soil particles and sediments. For this reason, ${ }^{137} \mathrm{Cs}$ was used to prove velocity and modality of soil redistribution through erosion processes in different environments (Walling 1998; Porto et al. 2001, 2003, 2016; Di Stefano et al. 2005; Porto and Walling 2012). However, the use of this technique requires the availability of expensive equipment that may be beyond the budget of most institutions. In this respect, rose the need to explore alternative indicators of soil erosion to fulfil the necessity to give information in areas where no measurements of ${ }^{137} \mathrm{Cs}$ are available. A previous study (Muscolo et al. 2014) individuated soil biological properties able to evidence, in a short-term, modification in soil quality in forest ecosystems. The authors explored the use of microbial biomass carbon (MBC), fluorescein diacetate (FDA) hydrolysis, and water-soluble phenols (WSP), in addition to soil organic matter (SOM), to assess the effects of forest management practices on soils, identifying WSP as an early warning indicator of soil quality changes.

Subsequent studies (Romeo et al. 2020a, b) investigated in a Fagus sylvatica L. stand, how different forest management practices (traditional thinning that removed $12 \%$ of total volume and innovative thinning that removed $27 \%$ of total volume) affected soil properties, using both ${ }^{137} \mathrm{Cs}$ and biological soil parameters. They demonstrated the existence of a strong correlation between ${ }^{137} \mathrm{Cs}$ and OC, $\mathrm{N}$ and WSP, indicating the latter parameters as possible early indicators of soil erosion. Based on the previous findings and considering that indicators of soil quality must be selected according to soil use and managements, our work hypothesis was to extend the investigation to other forests differently managed in order to have a more representative study.

The aim was to individuate the most suitable parameters to be used as possible early warning indicators of soil erosion in respect to the different forest management practices. In the present study, soil chemical parameters $\mathrm{pH}, \mathrm{EC}$, WSP, OC, $\mathrm{N}$ and $\mathrm{C} / \mathrm{N}$, have been selected on the basis of previous results (Romeo et al. 2020a) and evaluated against ${ }^{137} \mathrm{Cs}$, on a comparative basis, in Pinus nigra laricio Poir. and F. sylvatica forest subjected to 10 different types of management namely Undisturbed forest (UF), traditional thinning (TT), innovative thinning (IT), coppice (C), high monoplane forest (HM), biplane forest (HB), beech forest clear-cut (BCL), beech undisturbed forest (BUF), pine stand 52\% canopy cover (PF1) and pine stand 63\% canopy cover (PF2).

Our main objective was to identify universal and specific early warning indicators of soil degradation to precociously estimate how forest management affects the dynamic of soil processes to prevent irreversible damage to soil ecosystem functioning.

\section{Materials and methods}

\section{Study areas}

The investigation was carried out in three study areas [Mongiana (VV), Cinquemiglia (CS), and Ferraina (RC)] located across the Calabrian Apennine Mountain with beech and pine as vegetation (Fig. 1). In detail, eight different beech forests (Fagus sylvatica L.) and two Calabrian pine forests (Pinus nigra laricio Poir.), were selected for the investigation. Details of each study site are provided below.

\section{Mongiana site}

Mongiana study site (Fig. 1) is located in the Southern Apennine (Calabria Region), "Serre" mountains, in Mongiana (VV). The biogenetic reserve (Natura 2000 site) called "Marchesale" is a high forest of $F$. sylvatica which covers 1234 ha in charge of National Forest Service of Italy.

The main characteristics of the area are summarized in Table 1 . The experimental area is of ca. 30 ha, covered by 80 -year-old high beech forest. In this area, three sub-areas (three ha each) have been identified for each different silvicultural thinning $(3$ beech forest typologies $\times 3$ replicates $=9$ plots of $1000 \mathrm{~m}^{2}$ ). Specifically, an unmanaged zone for over 30 years (UF), an area traditionally managed (TT), and an area with an innovative treatment (IT) have been individualized (Table 2). Traditional management was a thinning from below with a moderate intensity, which eliminated all the dominated trees and the worst dominant trees (on average, ca. $12 \%$ of total volume resected). The innovative treatment 
Fig. 1 The study area (a) and the three selected locations

b : Ferraina, South Calabria,

Mongiana, central Calabria,

Cinquemiglia, North Calabria (a)

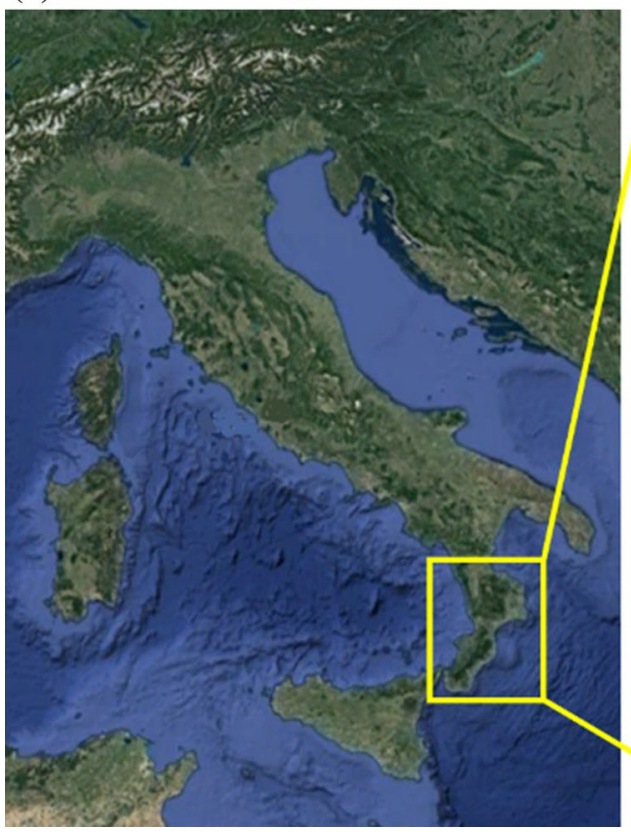

(b)

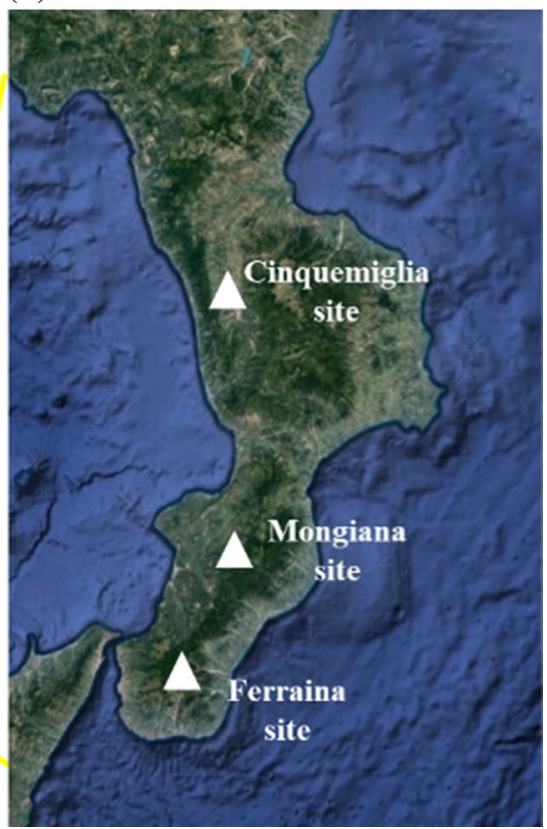

was an experimental thinning that consisted in keeping the 50 best trees per hectare by collecting 5 or 6 trees closer to them, regardless of their social position (on average, about $27 \%$ of the total volume removed). The best trees were identified according to their conformation in terms of diameter, height and vegetative vigour. In doing so, an attempt was made to further promote their development and evaluate the effects of this experimental management.

No significant differences were found between the dendrometric parameters in these areas before the silvicultural interventions (Picchio et al. 2016; Coletta et al. 2017). The three treatment sites were similar as slope, orientation and soil types. According to USDA soil classification, the soils are Inceptisols and Entisols (Soil Survey Staff 2010).

\section{Cinquemiglia site}

Cinquemiglia study site (Fig. 1) is located in the coastal chain in the northern part of Calabrian Apennines, within an area belonging to the "Natura 2000" site in Fuscaldo (CS).

The morphology of the area varies from valley with small streams to particularly steep slopes, up to flat areas. The slopes did not exceed $20 \%$. The surface horizon of the soil is, in this area, rich in organic matter, which gives the soil a typical dark brown colour, however its thickness may vary depending on the morphology and intensity of erosive phenomena. The main characteristics of the area are summarized in Table 1.

Within an area of about 394 ha and at an altitude ranging from 600 to $1200 \mathrm{~m}$ (a.s.l.), three different scenarios were identified, all with beech $(F$. sylvatica) as dominant species:
(C) a coppice; (HM) high forest with vertical monoplane structure; (HB) high forest with biplane vertical structure (Table 2).

For each scenario (C; HM; HB) three plots of $1000 \mathrm{~m}^{2}$ each and of similar slope were selected (3 forest typologies $\times 3$ replicates $=9$ plots).

The coppice (C) under study highlighted about 1300 stumps per hectare with wood volumes of about $300 \mathrm{~m}^{3}$ ha (Ciancio et al. 2007).

Dendrometric information of the monoplane forest $(\mathrm{F})$ can be deduced from previous works carried out in beech woods of the same type located in the Calabrian Apennines (Ciancio et al. 2008). This stand has a monoplane vertical structure of about $80-110$ years. The number of plants and the relative average volume were 381 ind. $\mathrm{ha}^{-1}$ and 548 $\mathrm{m}^{3} \mathrm{ha}^{-1}$, respectively (Ciancio et al. 2008).

The vertical biplane structure, obtained through targeted thinning operations over the decades (Ciancio et al. 2008), showed a number of plants between 60 and 90 ind. ha ${ }^{-1}$ aged between 100 and 120 years, and about $400-450$ ind. ha ${ }^{-1}$ to constitute the dominated layer (30-40 years) with final volumes of about $460 \mathrm{~m}^{3} \mathrm{~h}^{-1}$.

\section{Ferraina site}

Ferraina site (Fig. 1) is located within the highest slope and in the southernmost part of the Aspromonte National Park, in Samo (RC). The area is composed by well-structured but not particularly deeply soil, with moderate slopes ranging between 9 and $22 \%$. The main characteristics of the area are summarized in Table 1. 


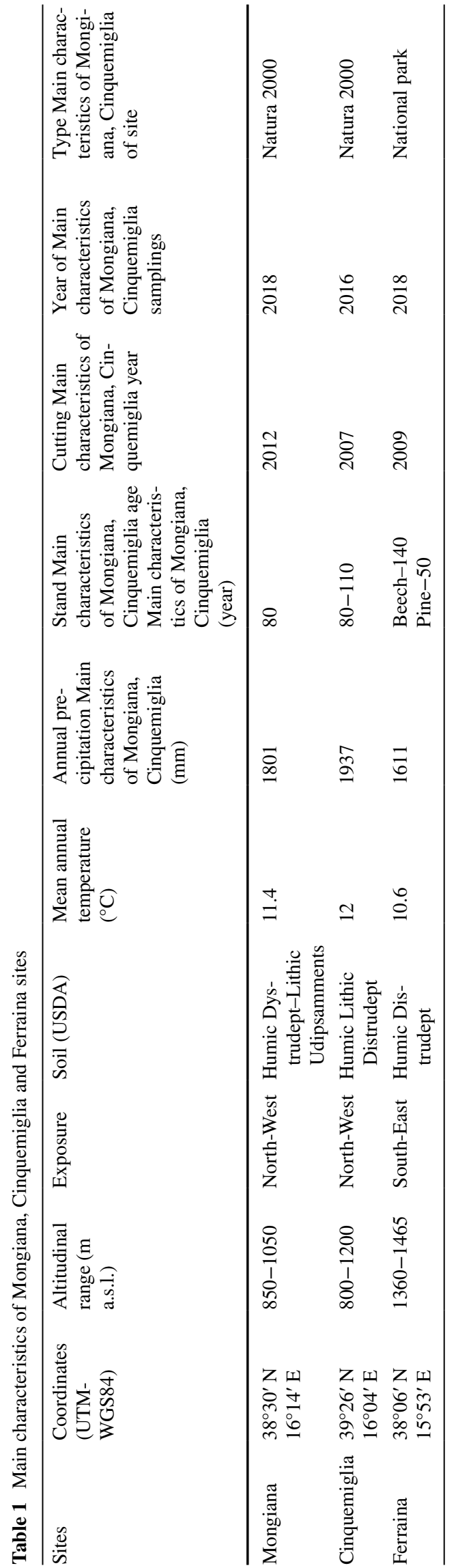

Table 2 Means and standard deviations $(n=3)$ of main dendrometric characteristics in Beech and Pine stands

\begin{tabular}{llccc}
\hline Sites & Types & $\begin{array}{l}\text { No. tree (ind. } \\
\left.\mathrm{ha}^{-1}\right)\end{array}$ & $\begin{array}{l}\text { Basal area } \\
\left(\mathrm{m}^{2} \mathrm{ha}^{-1}\right)\end{array}$ & $\begin{array}{l}\text { Volume }\left(\mathrm{m}^{3}\right. \\
\left.\mathrm{ha}^{-1}\right)\end{array}$ \\
\hline Mongiana & UF & $336 \pm 30$ & $38 \pm 4$ & $435 \pm 74$ \\
& TT & $503 \pm 11$ & $30 \pm 1$ & $302 \pm 15$ \\
& IT & $530 \pm 20$ & $27 \pm 2$ & $245 \pm 11$ \\
Cinquemiglia & C & $1526 \pm 51$ & $30 \pm 2$ & $301 \pm 31$ \\
& HM & $381 \pm 14$ & $39 \pm 3$ & $548 \pm 37$ \\
Ferraina & HB & $501 \pm 16$ & $33 \pm 3$ & $461 \pm 31$ \\
& PF1 & $870 \pm 19$ & $74 \pm 5$ & $699 \pm 44$ \\
& PF2 & $1482 \pm 38$ & $132 \pm 7$ & $1580 \pm 53$ \\
& BCL & - & - & - \\
& BUF & $821 \pm 18$ & $98 \pm 6$ & $1010 \pm 25$ \\
\hline
\end{tabular}

UF, undisturbed forest; TT, traditional thinning; IT, innovative thinning; C, coppice; HM, high monoplane forest; HB, biplane forest; BCL, beech forest clear-cut; BUF, beech undisturbed forest; PF1, Pine stand 52\% canopy cover; PF2, Pine stand 63\% canopy cover

For the purpose of this work, two stands with Calabrian pine (P. nigra laricio) and different canopy covers, and two stands with beech ( $F$. sylvatica) (one of which was cut in 2009) have been selected. Specifically, the two pine forest stands, namely PF1 and PF2 were constituted by 50 -year pine planted in the late 1960s during a massive re-afforestation program (ca. $150.000 \mathrm{ha}$ ). The two beech forest stands, namely BCL (beech forest clear-cut) and BUF (beech forest undisturbed) consisted of seminatural high beech forests (ca. 140 years old). BUF was not disturbed by cutting activities, excepted for a minimum removal of trees in the past decades; on the contrary, BCL was cleared-cut in 2009 and then left to evolve naturally.

In a previous contribution, Altieri et al. (2018) reported the results obtained from 4 small plots $\left(300 \mathrm{~m}^{2}\right)$ identified in this area. These plots have been revisited in 2018 and the area of sampling was extended to $1000 \mathrm{~m}^{2}$ for each plot. Similarly, two more replications of the above described plots have been established in order to be consistent with the sampling programme assumed for the other two sites. Finally, for each scenario (PF1, PF2, BCL and BUF) 3 plots of $1000 \mathrm{~m}^{2}$ each were considered in this investigation (4 forest typologies $\times 3$ replicates $=12$ plots).

The main dendrometric characteristics of each study sites are summarized in Table 2.

\section{Sampling procedure}

As it was described above, in each of the ten different scenarios (UF, TT, IT, C, HM, HB, PF1, PF2, BCL and BUF), three representative plots $\left(1000 \mathrm{~m}^{2}\right)$ were selected for sampling (see Fig. 2). In these 30 plots, three separate soil sampling campaigns were undertaken following the 
Fig. 2 The sampling strategy adopted in the plots established within the experimental sites

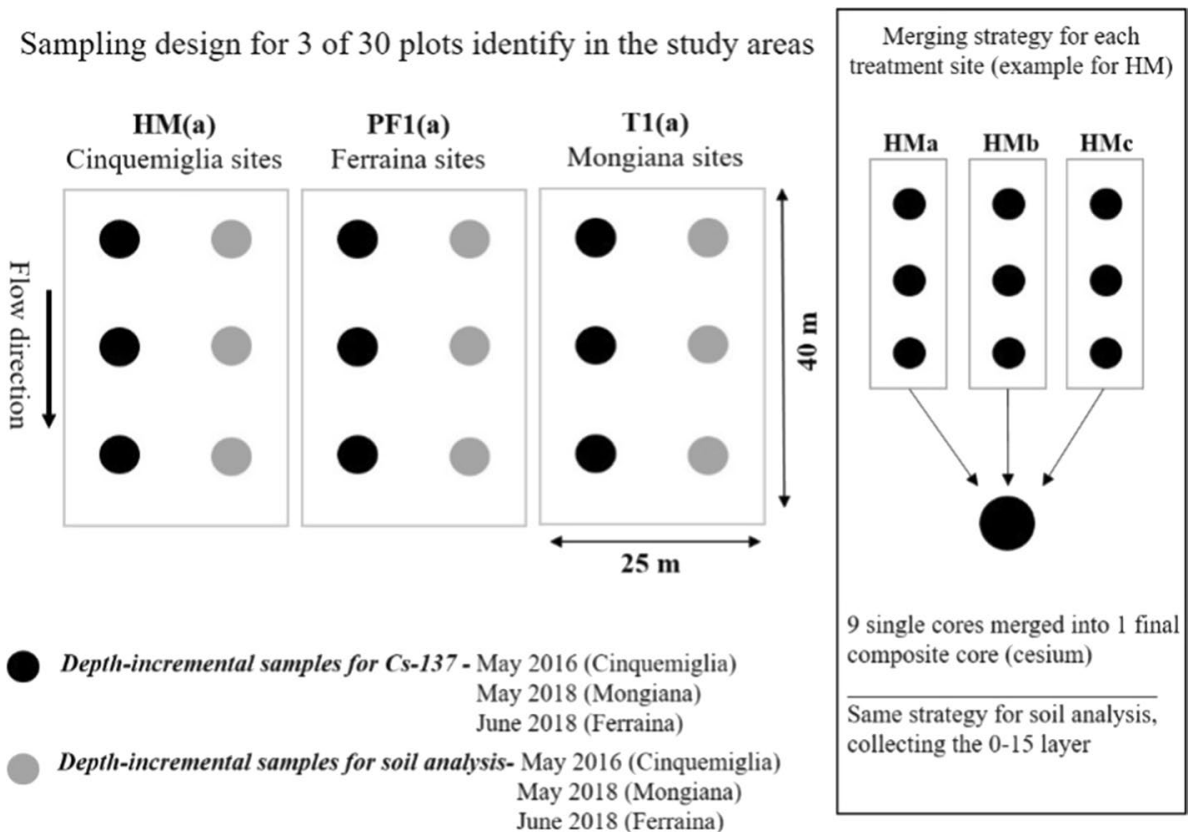

scheme illustrated in Fig. 2. Sampling campaigns were carried out in May 2016 in Cinquemiglia site, in May 2018 in Mongiana site, and in June 2018 in Ferraina site (Fig. 2).

Soil cores were collected to analyse ${ }^{137} \mathrm{Cs}$ and chemicalphysical properties, in areas with almost identical slope, to avoid of sampling near to the tree trunks to minimize the effect of stem flow on the final ${ }^{137} \mathrm{Cs}$ inventories.

Totally, 20 final composite soil cores (10 for radiometric measurements and 10 for chemical-physical and biological analysis) were picked up with a $10-\mathrm{cm}$-diameter steel core tube to a depth of ca. $35 \mathrm{~cm}$.

Each composite core used for ${ }^{137} \mathrm{Cs}$ and soil analysis come from 9 single sectioned cores (from 3 plots of the same treatment and sampling campaign) combined layer by layer (as shown in Fig. 2).

For the radionuclide measurements, the soil cores were divided every $2 \mathrm{~cm}$ (up to $30 \mathrm{~cm}$ in the case of caesium profiles) for better data accuracy while, only the first $15 \mathrm{~cm}$ of soil were considered following the same methodology for all other analyses.

This kind of sampling was needful to attain the activity of ${ }^{137} \mathrm{Cs}$ distributed in the soil profile and to account for micro scale variability. The first $15 \mathrm{~cm}(0-15 \mathrm{~cm})$ of soil have been taken into account for soil analyses, following the scheme used for radionuclides. Soil samples were air-dried, and sieved ( $2 \mathrm{~mm}$ mesh). For the radiometric assay, samples were oven-dried at $105^{\circ} \mathrm{C}$ for $48 \mathrm{~h}$, sieved to separate the $<2 \mathrm{~mm}$ fraction and packed in plastic pots or Petri dishes to detect ${ }^{137} \mathrm{Cs}$ activity by gamma spectroscopy.

\section{Radiometric analyses for ${ }^{137} \mathrm{Cs}$ content}

${ }^{137} \mathrm{Cs}$ activity and its subsequent vertical distribution in the soil profile was detected by using a gamma spectrometry. Two Canberra p-type HPGe detectors, model GX4020, were utilized for the analyses as reported in a previous work of Romeo et al. (2020a).

\section{Soil analysis}

pH was detected as reported in Romeo et al. (2020a). Electric conductibility (EC) was assessed by using Hanna instrument conductivity meter in a ratio of 1:5 residue/ distilled water. Total water-soluble phenols (WSP) were assessed with Folin-Ciocalteu reagent (Box 1983). Tannic acid the standard used, WSP concentration was expressed as tannic acid equivalents. Total organic carbon (C) was determined following the method of Walkley and Black (1934), and subsequently converted to organic matter by multiplying the percentage of carbon by 1.72 . Total nitrogen $(\mathrm{N})$ was measured following the Kjeldahl method (1883).

\section{Statistical analysis}

To explore relationships among soil parameters $(0-15 \mathrm{~cm}$ depth) and six different forest stands (9 situations), datasets were analysed using Pearson's correlations, Multivariate Analysis of Variance (MANOVA) and T-test for paired 
values. Correlations was carried out using the software PAST (Hammer et al. 2001).

MANOVA analysis was carried out for evaluating the effects of different types of forest and their interaction on the set of soil parameters and ${ }^{137} \mathrm{Cs}$. Finally, a T-test was used for paired values to evaluate significant differences. This last analysis allowed to verify if the thinning influenced the properties of the soil, including the activity of the radionuclide ${ }^{137} \mathrm{Cs}$ and if the impacts were similar. Manova and T-test were carried out using SPSS software (IBM Corp. 2012).

\section{Results and discussion}

\section{${ }^{137}$ Cs profiles distribution}

The ${ }^{137}$ Cs distribution profiles, reported in Figs. 3, 4 and 5, showed a decreasing trend with soil depth, typical of forest stands (Porto et al. 2003). The depth scale in Figs. 3, 4 and
5 , is plotted as cumulative mass $\left(\mathrm{kg} \mathrm{m}^{-2}\right)$, instead of depth (m), to avoid to consider down core variations in soil bulk density and to make the profiles comparable one another.

In Mongiana site, the ${ }^{137} \mathrm{Cs}$ profile in UF, here considered as reference site, showed an inventory value of $4577 \mathrm{~Bq} \mathrm{~m}^{-2}$ (Fig. 3). In TT and IT, the ${ }^{137} \mathrm{Cs}$ profiles (Fig. 3) showed inventory values of 3620 and $1490 \mathrm{~Bq} \mathrm{~m}^{-2}$, respectively. Both profiles documented inventory values lower than the reference value and, for this reason, they are both indicative of soil erosion. However, the much lower ${ }^{137} \mathrm{Cs}$ inventory in IT suggested that the triggering of erosive phenomena was very pronounced in this area compared to TT area where a traditional thinning was performed. In terms of ${ }^{137} \mathrm{Cs}$ activity, a visual inspection of the profiles shown in Fig. 3 suggested that the soil surface of the areas under forest management (TT and IT), had lower ${ }^{137} \mathrm{Cs}$ concentrations (between 50 and $100 \mathrm{~Bq} \mathrm{~kg}^{-1}$ ) than the reference area. This condition confirmed that the top soil of the profiles related to TT and IT was removed by erosion.

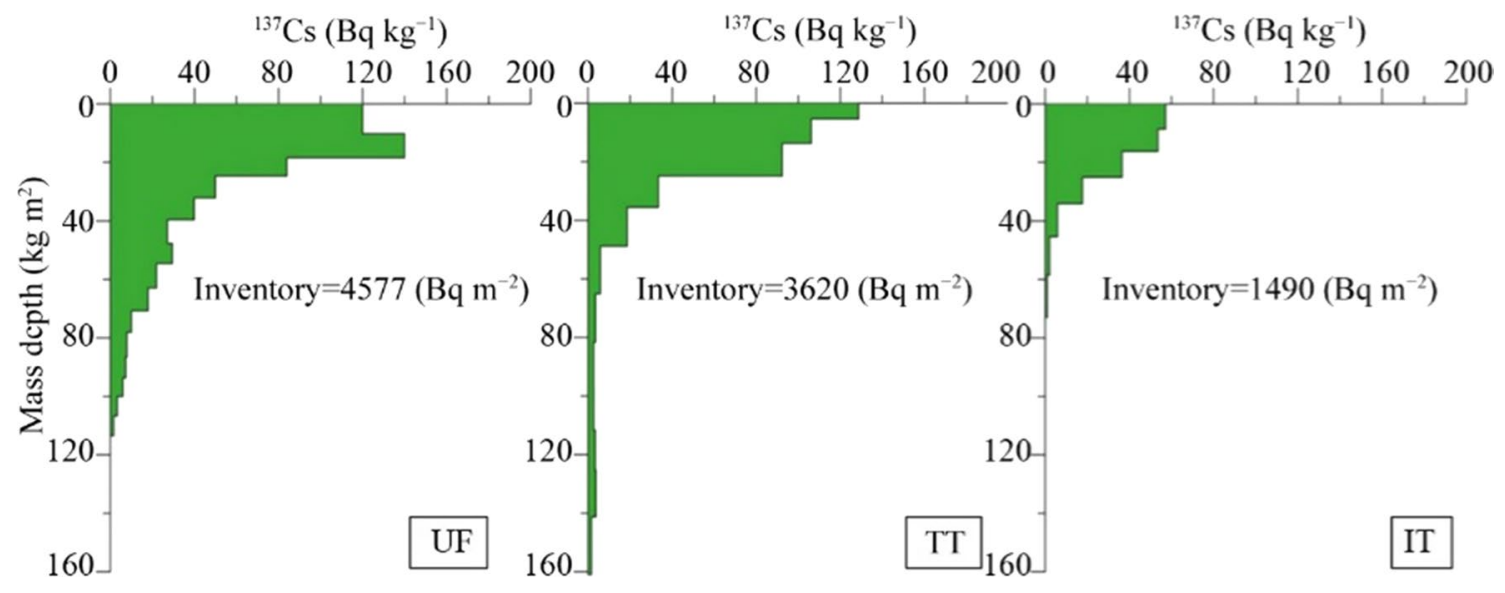

Fig. 3 Cesium profiles distribution referred to the Mongiana sites (UF undisturbed forest, $T T$ traditional thinning, IT innovative thinning)

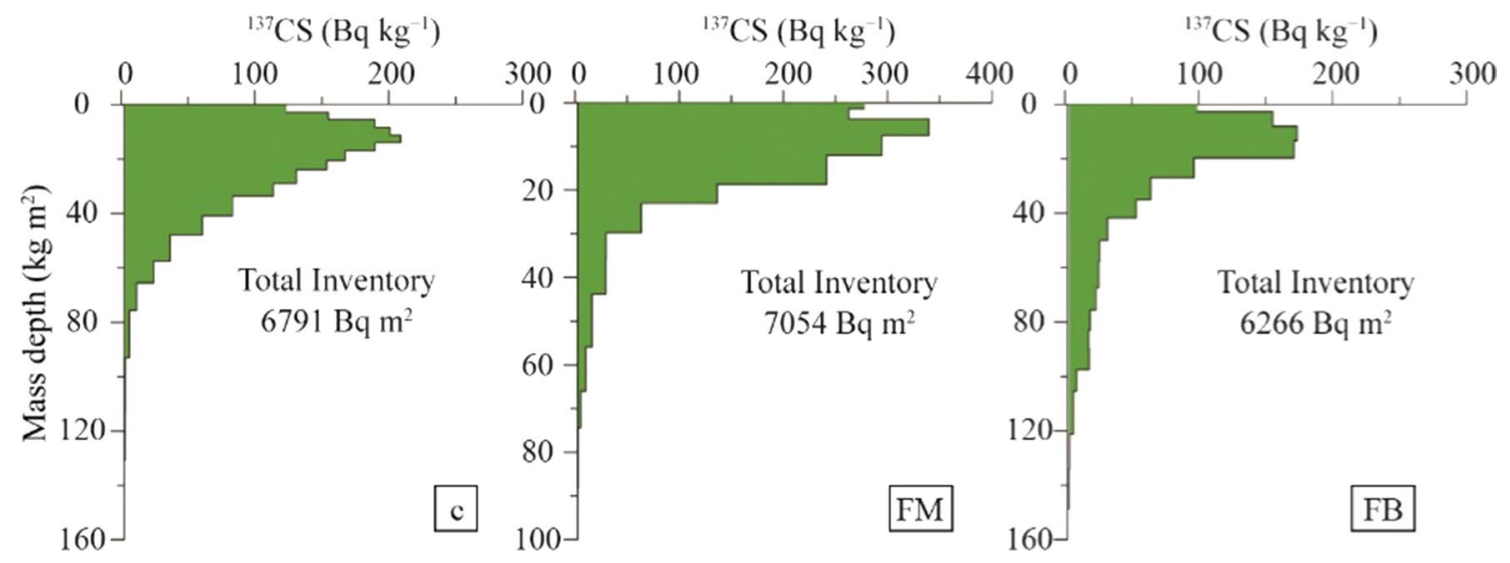

Fig. 4 Cesium profiles distribution referred to the Cinquemiglia sites ( $C$ coppice stand, $H M$ high monoplane forest, $H B$ high biplane forest) 
Fig. 5 Cesium profiles distribution referred to the Ferraina sites [PF1 (52\% canopy cover) and PF2 (63\% canopy cover), pine stands; BCL, beech forest clear-cut; BUF-beech undisturbed forest]

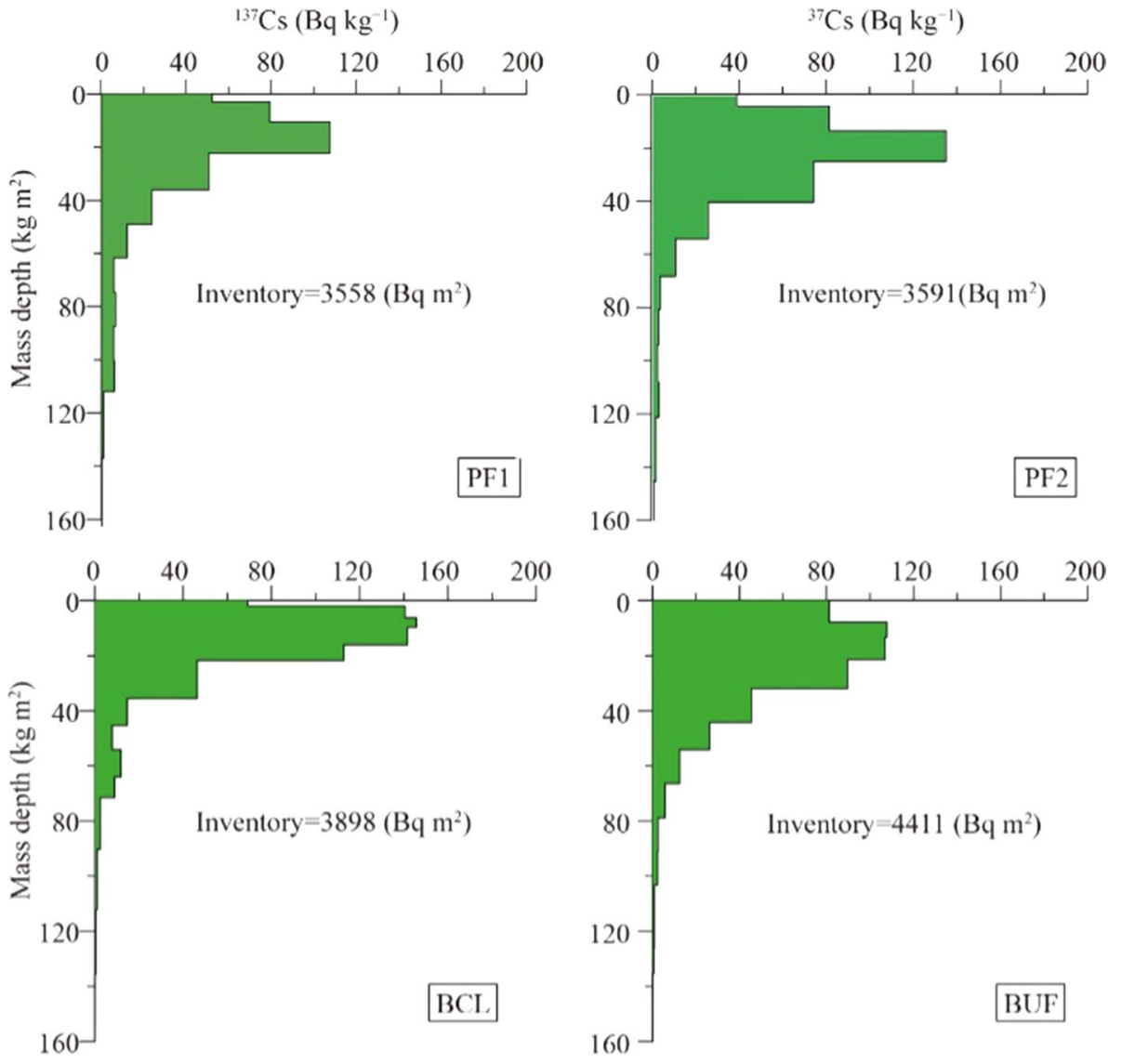

The ${ }^{137} \mathrm{Cs}$ profiles in Cinquemiglia site (C, HM, HB) documented a higher radionuclide inventory than in Mongiana area (Fig. 4). This was mainly due to the different geographical location and the different ${ }^{137} \mathrm{Cs}$ fallout occurring in this area that is linked to a different rainfall regime. The rainfall data obtained from the meteorological station in 'Laghitello' (located very close to the study area) showed, for the period 1940-2000, a mean annual precipitation of $1937 \mathrm{~mm}$ that makes this territory as one of the most humid areas of Calabria. The ${ }^{137} \mathrm{Cs}$ profile related to the monoplane forest HM (Fig. 4) documented a total inventory value of $7054 \mathrm{~Bq} \mathrm{~m}^{-2}$. This area, due to forest stability conditions, less management activities and minor disturb in its composition, has been individuated as a reference area and it can be used for comparison with the other two scenarios in the same site.

Conversely, erosive phenomena occurred in the coppice managed area, characterised by a ${ }^{137} \mathrm{Cs}$ inventory of $6791 \mathrm{~Bq} \mathrm{~m}^{-2}$, and in the biplane forest $\left({ }^{137} \mathrm{Cs}\right.$ inventory $=6266 \mathrm{~Bq} \mathrm{~m}^{-2}$ ), where a decrease in more than $100 \mathrm{~Bq} \mathrm{~kg}^{-1}$ in the surface soil layer compared to $\mathrm{HM}$ was observed both for $\mathrm{C}$ and $\mathrm{HB}$ areas (Fig. 4).

The ${ }^{137} \mathrm{Cs}$ profiles obtained from the pine stands located in Ferraina site (Fig. 5) showed no significant differences between the two scenarios characterised by different tree cover. In addition to a similar distribution along the soil profile, the PF1 area indicated a similar inventory value of ${ }^{137} \mathrm{Cs}\left(3558 \mathrm{~Bq} \mathrm{~m}^{-2}\right)$ compared to the PF2 area $\left({ }^{137} \mathrm{Cs}\right.$ inventory $\left.=3591 \mathrm{~Bq} \mathrm{~m}^{-2}\right)$. In the clear-cut beech stands there was a decrease in ${ }^{137} \mathrm{Cs}$ inventory $\left(4894 \mathrm{~Bq} \mathrm{~m}^{-2}\right.$ ) compared to the undisturbed area $\left(5059 \mathrm{~Bq} \mathrm{~m}^{-2}\right)$ that was selected on purpose (see Altieri et al. 2018). The lack of tree cover in BCL certainly influenced the triggering of erosive processes. In the same area of Ferraina, the lowest values can be observed in pine stands compared to beech stands, a phenomenon mainly due to the tree canopy conformations and to the degree of coverage they can offer.

Merging the profiles shown in Fig. 3, 4 and 5, with the bulk density values, it was possible to calculate ${ }^{137} \mathrm{Cs}$ inventory $\left(\mathrm{Bq} \mathrm{m}^{-2}\right)$ and mass activity $\left(\mathrm{Bq} \mathrm{kg}^{-1}\right)$ for a fixed depth. This calculation was made for the soil depth corresponding to the first $15 \mathrm{~cm}$, to render feasible the paragon with the other soil properties of the corresponding layer.

These results evidenced important differences between the estimates of soil erosion in relation to the type of treatment on the basis of the evident decrease in ${ }^{137} \mathrm{Cs}$ in respect to the intensity of the thinning. Our data are in agreement with the work of Romeo et al. (2020a) carried out in a Fagus sylvatica stand with different thinning treatments. The authors reported that the amount of ${ }^{137} \mathrm{Cs}$ decreased, and 
its greatest decrease was observed when the intensity of the treatment increased. The data obtained contribute to strength the use of ${ }^{137} \mathrm{Cs}$ as tracer to display soil erosion processes in forestry areas.

\section{Soil properties}

In Mongiana site, the $\mathrm{pH}$ was slightly higher in innovative thinning (IT) than in TT and UF areas. The soil were sub-acid with $\mathrm{pH}$ values ranging from 5.4 to 6 (Table 3). Electrical conductivity did not vary significantly among the treatments (Table 3) while WSP, OC, N (UF $>$ TT $>$ IT) decreased with increasing forest thinning (Table 3). More thinning intensity more the decline was. All the parameters were significantly and positively correlated with ${ }^{137} \mathrm{Cs}(\mathrm{Bq}$ $\mathrm{m}^{-2}, \mathrm{~Bq} \mathrm{~kg}^{-1}$ ) (Table 3).
In Cinquemiglia site, the $\mathrm{pH}$ did not show significant differences between the treatments, ranging from $4.5(\mathrm{HB})$ to 5 (C). The highest value of EC $(575 \mu \mathrm{S})$ was observed in the coppice area (C), while the lowest $(493 \mu \mathrm{S})$ in HM (Table 3). Also, in this area, WSP, OC, $\mathrm{N}$ decreased when thinning intensity increased with the highest values in $\mathrm{HM}$, followed by $\mathrm{C}$ and $\mathrm{HB}(\mathrm{HM}>\mathrm{C}>\mathrm{HB})$. All the parameters were significantly and positively correlated with ${ }^{137} \mathrm{Cs}\left(\mathrm{Bq} \mathrm{m}^{-2}, \mathrm{~Bq}\right.$ $\mathrm{kg}^{-1}$ ), showing the same trend of Mongiana (Table 3).

In Ferraina the $\mathrm{pH}$ was slightly lower in BCL than in the other sites (PF1, PF2, BUF). In general $\mathrm{pH}$ varied from 5.3 to 6.1 (Table 3). The highest value of EC $(411 \mu \mathrm{S})$ was observed in the undisturbed beech forest (BUF), while the lowest $(162 \mu \mathrm{S}$ ) in PF1 (Table 3). WSP, OC, N followed the same trend (PF2 $>$ PF1; BUF $>$ BCL) of the other two sites decreasing with increasing forest thinning (Table 3). WSP,

Table 3 Mean values and standard deviations of soil parameters referred to $0-15 \mathrm{~cm}$ soil layer

\begin{tabular}{|c|c|c|c|c|c|c|c|c|}
\hline ID & $\mathrm{pH}$ & $\mathrm{EC}$ & WSP & $\mathrm{OC}$ & $\mathrm{N}$ & $\mathrm{C} / \mathrm{N}$ & $\mathrm{Cs} \mathrm{m}^{2}$ & $\mathrm{Cs} \mathrm{kg}^{-1}$ \\
\hline C & $5.0 \pm 0.5^{\mathrm{a}}$ & $575 \pm 24^{\mathrm{a}}$ & $456 \pm 7^{b}$ & $12.1 \pm 0.2^{\mathrm{b}}$ & $0.71 \pm 0.01^{\mathrm{b}}$ & $17 \pm 0.4^{\mathrm{b}}$ & $6102 \pm 2^{b}$ & $254 \pm 0.8^{\mathrm{b}}$ \\
\hline HM & $4.7 \pm 0.1^{\mathrm{a}}$ & $493 \pm 25^{\mathrm{b}}$ & $484 \pm 13^{\mathrm{a}}$ & $17.2 \pm 0.2^{\mathrm{a}}$ & $0.85 \pm 0.04^{\mathrm{a}}$ & $20 \pm 1^{\mathrm{a}}$ & $7063 \pm 3^{\mathrm{a}}$ & $289 \pm 1^{\mathrm{a}}$ \\
\hline $\mathrm{HB}$ & $4.5 \pm 0.1^{\mathrm{a}}$ & $535 \pm 30^{\mathrm{ab}}$ & $400 \pm 7^{\mathrm{c}}$ & $11.5 \pm 0.2^{\mathrm{c}}$ & $0.64 \pm 0.02^{\mathrm{c}}$ & $18 \pm 0.9^{b}$ & $5777 \pm 2^{c}$ & $144 \pm 1^{\mathrm{c}}$ \\
\hline UF & $5.4 \pm 0.1^{\mathrm{b}}$ & $176 \pm 2^{\mathrm{a}}$ & $259 \pm 6^{\mathrm{a}}$ & $11.5 \pm 0.4^{\mathrm{a}}$ & $0.57 \pm 0.01^{\mathrm{a}}$ & $20 \pm 0.6^{\mathrm{a}}$ & $4078 \pm 4^{\mathrm{a}}$ & $113 \pm 0.4^{\mathrm{a}}$ \\
\hline $\mathrm{TT}$ & $5.5 \pm 0.1^{b}$ & $173 \pm 1^{\mathrm{a}}$ & $155 \pm 7^{\mathrm{b}}$ & $6.5 \pm 0.2^{b}$ & $0.43 \pm 0.01^{\mathrm{b}}$ & $15 \pm 0.4^{\mathrm{b}}$ & $3393 \pm 3^{b}$ & $73 \pm 0.7^{b}$ \\
\hline IT & $6.0 \pm 0.1^{\mathrm{a}}$ & $173 \pm 3^{a}$ & $67 \pm 5^{\mathrm{c}}$ & $3.1 \pm 0.1^{\mathrm{c}}$ & $0.23 \pm 0.01^{\mathrm{c}}$ & $13 \pm 0.3^{c}$ & $1490 \pm 2^{c}$ & $34 \pm 0.2^{\mathrm{c}}$ \\
\hline PF1 & $6.1 \pm 0.1^{\mathrm{a}}$ & $162 \pm 3^{\mathrm{d}}$ & $289 \pm 3^{\mathrm{d}}$ & $8.6 \pm 0.4^{c}$ & $0.64 \pm 0.01^{\mathrm{c}}$ & $14 \pm 0.2^{\mathrm{c}}$ & $3306 \pm 1^{\mathrm{d}}$ & $77 \pm 0.9^{c}$ \\
\hline $\mathrm{PF} 2$ & $5.9 \pm 0.2^{\mathrm{a}}$ & $221 \pm 3^{c}$ & $376 \pm 1^{\mathrm{c}}$ & $9.5 \pm 0.5^{c}$ & $0.68 \pm 0.02^{\mathrm{c}}$ & $14 \pm 0.7^{\mathrm{c}}$ & $3415 \pm 2^{c}$ & $72 \pm 0.6^{\mathrm{d}}$ \\
\hline BCL & $5.3 \pm 0.1^{\mathrm{b}}$ & $354 \pm 2^{\mathrm{b}}$ & $412 \pm 4^{\mathrm{b}}$ & $13.2 \pm 0.2^{\mathrm{b}}$ & $0.79 \pm 0.02^{\mathrm{b}}$ & $17 \pm 0.5^{\mathrm{b}}$ & $3597 \pm 3^{b}$ & $151 \pm 0.8^{\mathrm{a}}$ \\
\hline BUF & $5.8 \pm 0.2^{\mathrm{a}}$ & $411 \pm 3^{a}$ & $525 \pm 2^{\mathrm{a}}$ & $15.4 \pm 0.5^{\mathrm{a}}$ & $0.85 \pm 0.02^{\mathrm{a}}$ & $18 \pm 0.2^{\mathrm{a}}$ & $4296 \pm 3^{\mathrm{a}}$ & $108 \pm 1^{\mathrm{b}}$ \\
\hline$p$ value & $\leq 0.05$ & $\leq 0.05$ & $\leq 0.05$ & $\leq 0.05$ & $\leq 0.05$ & $\leq 0.05$ & $\leq 0.05$ & $\leq 0.05$ \\
\hline
\end{tabular}

pH $\left(\mathrm{H}_{2} \mathrm{O}\right)$; electrical conductivity $\left(\mathrm{EC}, \mu \mathrm{S} \mathrm{cm}^{-1}\right)$; water soluble phenols (WSP, $\mu \mathrm{g}$ TAE $\mathrm{g}^{-1}$ dry soil); organic carbon $(\mathrm{OC}, \%)$; total nitrogen $(\mathrm{N}, \%) ; \mathrm{C} / \mathrm{N}$ ratio; ${ }^{137} \mathrm{Cs}\left(\mathrm{Bq} \mathrm{m}^{2}, \mathrm{~Bq} \mathrm{~kg}^{-1}\right)$. For each parameter the sample size was $\mathrm{n}=3$ for treatment $(\mathrm{C}$, coppice stand; HM, high monoplane forest; HB, high biplane forest; UF (b), undisturbed forest; TT (b), traditional thinning; IT (b), innovative thinning; PF1 (52\% canopy cover) and PF2 (63\% canopy cover), pine stands; BCL, beech forest clear-cut; BUF, beech undisturbed forest). Means in the same column followed by the same letter are not statistically different at $p \leq 0.05$ (Tukey test) $n=3$

Table 4 Pearson's correlations coefficient $(r)$ between ${ }^{137} \mathrm{Cs}(\mathrm{Bq}$ $\mathrm{m}^{-2}, \mathrm{~Bq} \mathrm{~kg}^{-1}$ ) and the soil parameters ( $\mathrm{pH}$; EC; WSP; OC; $\mathrm{N} ; \mathrm{C} / \mathrm{N}$ ), referred to $0-15 \mathrm{~cm}$ soil layer in $(\mathrm{C}$, coppice stand; HM, high mono- plane forest; HB, high biplane forest; UF, undisturbed forest; TT, traditional thinning; IT, innovative thinning; BCL, beech forest clearcut; BUF, beech undisturbed forest; PF1 and PF2, pine stands)

\begin{tabular}{|c|c|c|c|c|c|c|c|c|}
\hline \multirow[t]{3}{*}{ Soil parameters } & \multicolumn{2}{|c|}{ Fuscaldo } & \multicolumn{2}{|c|}{ Mongiana } & \multicolumn{2}{|c|}{ Ferraina } & \multicolumn{2}{|c|}{ Ferraina } \\
\hline & \multicolumn{2}{|c|}{ C-HM-HB } & \multicolumn{2}{|c|}{ UF-TT-IT } & \multicolumn{2}{|c|}{ BCL-BUF } & \multicolumn{2}{|c|}{ PF1-PF2 } \\
\hline & $\mathrm{Cs} \mathrm{m}^{2}$ & $\mathrm{Cs} \mathrm{kg}^{-1}$ & $\mathrm{Cs} \mathrm{m}^{2}$ & $\mathrm{Cs} \mathrm{kg}^{-1}$ & $\mathrm{Cs} \mathrm{m}^{2}$ & $\mathrm{Cs} \mathrm{kg}^{-1}$ & $\mathrm{Cs} \mathrm{m}^{2}$ & $\mathrm{Cs} \mathrm{kg}^{-1}$ \\
\hline \multicolumn{9}{|l|}{$\mathrm{pH}$} \\
\hline $\mathrm{EC}$ & & & & & $0.82 *$ & $0.86 * *$ & $0.92 * *$ & $0.93 * *$ \\
\hline WSP & $0.82 * *$ & $0.96^{* *}$ & $0.95^{* *}$ & $0.99 * *$ & $0.99 * *$ & $0.99 * *$ & $0.99 * *$ & $0.96 * *$ \\
\hline $\mathrm{OC}$ & $0.99 * *$ & $0.91 * *$ & $0.93 * *$ & $0.99 * *$ & $0.95^{* *}$ & $0.95 * *$ & $0.89 *$ & \\
\hline $\mathrm{N}$ & $0.94 * *$ & $0.94 * *$ & $0.99 * *$ & $0.99 * *$ & $0.89 *$ & $0.87 *$ & $0.82 *$ & $0.86^{*}$ \\
\hline $\mathrm{C} / \mathrm{N}$ & $0.84 * *$ & & $0.86^{* *}$ & $0.96 * *$ & $0.93^{* *}$ & $0.92 * *$ & & \\
\hline
\end{tabular}

Significant at $* p<0.05 ; * *<0.01$ 
OC, $\mathrm{N}$ were positively and significantly correlated to ${ }^{137} \mathrm{Cs}$ $\left(\mathrm{Bq} \mathrm{m}^{-2}\right.$ ) confirming the data obtained in the other two sites.

The Pearson's correlation coefficient between ${ }^{137} \mathrm{Cs}$ and soil parameters (Table 4) showed that $\mathrm{pH}$ was not correlated with ${ }^{137} \mathrm{Cs}$ and with the other chemical soil parameters. $\mathrm{EC}$ and $\mathrm{C} / \mathrm{N}$ showed a poor correlation. On the contrary, a strong correlation between ${ }^{137} \mathrm{Cs}$ and $\mathrm{OC}, \mathrm{N}$ and WSP in all the study sites and in all the treatments was observed (Table 4). The majority of previous works demonstrated a strong correlation mainly between soil organic matter and ${ }^{137}$ Cs (Zhang et al. 2006; Teramage et al. 2013), Nakamaru et al. (2007) and Fujii et al. (2018) explained this correlation with the ability of SOM to adsorb ${ }^{137} \mathrm{Cs}$ in an exchangeable forms, enhancing also its mobility. Successively, Romeo et al (2020a) evidenced for the first time in soil under Fagus sylvatica subject to different thinning a correlation between ${ }^{137} \mathrm{Cs}$ and other soil parameters such as water soluble phenols and nitrogen. Our results confirm in different forest stands and under different forest system treatments the established relationship between ${ }^{137} \mathrm{Cs}$ and other soil parameters, providing an alternative diagnostic tool through the use of soil chemical parameters as indicators to quantitatively evaluate the soil losing in the context of forest management.

\section{Conclusion}

Understanding how forest management can affect soil performance and processes in a short term in a cheap and easy way is now feasible. The selected indicators, in respect to ${ }^{137} \mathrm{Cs}$, are sensitive to changes external induced, able to integrate and to correlate to other soil properties, reproducible in the use and inexpensive. The results of this study confirm, even under different vegetation types and thinning practices, the interconnection of WSP, C, N with ${ }^{137} \mathrm{Cs}$ and the ability of these chemical soil parameters to give early indications on the triggering of erosive processes. This study can be a useful support to predict the dynamic behavior of soil processes at the impact of management practices representing a relevant tool for determining the sustainability of forest practices in a short period of time. The estimation of erosion velocity given by the ${ }^{137} \mathrm{Cs}$ indicates that attention must be paid when cutting operations in forest areas are planned. The estimation of erosion velocity given by the ${ }^{137} \mathrm{Cs}$ technique points out that it is necessary to properly plan cutting operations in forest areas to avoid triggering of soil erosion process.

Acknowledgements The study was supported by the Coordinated Research Project (CRP) D1.50.17 within the framework of the International Atomic Energy Agency (IAEA). The authors are also indebted to the ARPACAL for providing rainfall data used in this study.
Funding Open Access funding provided by Università degli Studi Mediterranea di Reggio Calabria.

Open Access This article is licensed under a Creative Commons Attribution 4.0 International License, which permits use, sharing, adaptation, distribution and reproduction in any medium or format, as long as you give appropriate credit to the original author(s) and the source, provide a link to the Creative Commons licence, and indicate if changes were made. The images or other third party material in this article are included in the article's Creative Commons licence, unless indicated otherwise in a credit line to the material. If material is not included in the article's Creative Commons licence and your intended use is not permitted by statutory regulation or exceeds the permitted use, you will need to obtain permission directly from the copyright holder. To view a copy of this licence, visit http://creativecommons.org/licenses/by/4.0/.

\section{References}

Altieri V, De Franco S, Lombardi F, Marziliano PA, Menguzzato G, Porto P (2018) The role of silvicultural systems and forest types in preventing soil erosion processes in mountain forests: a methodological approach using Caesium-137 measurements. J Soils Sediment 18(12):3378-3387. https://doi.org/10.1007/ s11368-018-1957-8

Balboa-Murias MA, Rodríguez-Soalleiro R, Merino A, ÁlvarezGonzález JG (2006) Temporal variations and distribution of carbon stocks in aboveground biomass of radiata pine and maritime pine pure stands under different silvicultural alternatives. Forest Ecol Manag 237(1-3):29-38

Box J (1983) Investigation of the Folin-Ciocalteau phenol reagent for the determination of polyphenolic substances in natural waters. Water Res 17(5):511-525

Ciancio O, Iovino F, Menguzzato G, Nicolaci A (2007) Interventi selvicolturali in cedui di faggio che hanno superato il turno consuetudinario e valutazione della biomassa legnosa ritraibile. L'Italia Forestale e Montana 62(5-6):339-353

Ciancio O, Iovino F, Menguzzato G, Nicolaci A (2008) Struttura e trattamento in alcune faggete dell'Appennino meridionale. L'Italia Forestale e Montana 63(6):465-481

Coletta V, Pellicone G, Bernardini V, De Cinti B, Froio R, Marziliano PA, Matteucci G, Ricca N, Turco R, Veltri A (2017) Short-time effect of harvesting methods on soil respiration dynamics in a beech forest in southern Mediterranean Italy. iForest 10(3):645

De Roo A, Wesseling C, Ritsema C (1996) LISEM: a single-event physically based hydrological and soil erosion model for drainage basins. I: theory, input and output. Hydrol Process 10(8):1107-1117

Di Stefano C, Ferro V, Porto P, Rizzo S (2005) Testing a spatially distributed sediment delivery model (SEDD) in a forested basin by cesium-137 technique. J Soil Water Conserv 60(3):148-157

Food and Agriculture (2017) Driving action across the 2030 agenda for sustainable development, pp 39, (CFAO, 2017 I7454EN/1/07.17. www.fao.org

Fujii M, Ono K, Yoshimura C, Miyamoto M (2018) The role of autochthonous organic matter in radioactive cesium accumulation to riverine fine sediments. Water Res 137:18-27

Hammer Ø, Harper DA, Ryan PD (2001) PAST: paleontological statistics software package for education and data analysis. Palaeontol Electron 4:9

IBM Corp. Released (2012) IBM SPSS statistics for windows, Version 21.0. IBM Corp, Armonk, NY 
Johnson DW (1992) Effects of forest management on soil carbon storage Natural Sinks of $\mathrm{CO}_{2}$. Springer, Berlin, pp 83-120

Kjeldahl J (1883) Neue methode zur bestimmung des stickstoffs in organischen körpern. Zh Anal Chem 22:366-382

Morgan RPC, Quinton JN, Rickson RJ (1992) Eurosem documentation manual. Silsoe College, Silsoe, p 34

Muscolo A, Panuccio MR, Mallamaci C, Sidari M (2014) Biological indicators to assess short-term soil quality changes in forest ecosystems. Ecol Indic 45:416-423

Nakamaru Y, Ishikawa N, Tagami K, Uchida S (2007) Role of soil organic matter in the mobility of radiocesiumin agricultural soils common in Japan. Colloids Surf A: Physicochem Eng Asp 306:111-117

Neary DG, Klopatek C, DeBano LF, Ffolliott PF (1999) Fire effects on belowground sustainability: a review and synthesis. For Ecol Manag 122:51-71

Nilsen P, Strand LT (2008) Thinning intensity effects on carbon and nitrogen stores and fluxes in a Norway Spruce (Picea abies (L.) Karst.) stand after 33 years. For Ecol Manag 256:201-208

Picchio R, Spina R, Calienno L, Venanzi R, Lo Monaco A (2016) Forest operations to implement silvicultural treatments for multiple purposes. From the experience of LIFE+ ManFor C. BD to the Manual of Best Practices in Sustainable Forest Management. Ital J Agron 11:1-175

Porto P, Walling DE (2012) Using plot experiments to test the validity of mass balance models employed to estimate soil redistribution rates from ${ }^{137} \mathrm{Cs}$ and ${ }^{210} \mathrm{~Pb}_{\mathrm{ex}}$ measurements. Appl Radiat Isot 70:2451-2459

Porto P, Walling DE, Ferro V (2001) Validating the use of caesium-137 measurements to estimate soil erosion rates in a small drainage basin in Calabria, southern Italy. J Hydrol 248:93-108

Porto P, Walling DE, Ferro V, Di Stefano C (2003) Validating erosion rate estimates by caesium-137 measurements for two small forested catchments in Calabria, Southern Italy. Land Degrad Dev 14:389-408

Porto P, Walling DE, La Spada C, Callegari G (2016) Validating the use of $137 \mathrm{Cs}$ measurements to derive the slope component of the sediment budget of a small catchment in southern Italy. Land Degrad Dev 27:798-810
Renard KG, Freimund JR (1994) Using monthly precipitation data to estimate the R-factor in the revised USLE. J Hydrol 157:287-306

Romeo F, Porto P, Keibliger K, Mentler A, Muscolo A (2020a) Soil biological indicators and caesium-137 to estimate soil erosion in areas with different forest system management. Eur J For Res 139(1):67-81

Romeo F, Settineri G, Sidari M, Mallamaci C, Muscolo A (2020b) Responses of soil quality indicators to innovative and traditional thinning in a beech (Fagus sylvatica L.) forest. Forest Ecol Manag 465:118106

Soil Survey Staff (2010) Keys to soil taxonomy, 11th edn. Natural Resources Conservation Service, USDA, Washington, DC, USA, p 338. http://www.nrcs.usda.gov/Internet/FSE_DOCUMENTS/ nrcs142p2_050915.pdf

Teramage MT, Onda Y, Kato H, Wakiyama Y, Mizugaki S, Hiramatsu S (2013) The relationship of soil organic carbon to ${ }^{210} \mathrm{Pbex}$ and ${ }^{137} \mathrm{Cs}$ during surface soil erosion in a hillslope forested environment. Geoderma 192:59-67

Walkley A, Black IA (1934) An examination of the Degtjareff method for determining soil organic matter and a proposed modification of the chromic acid titration method. Soil Sci 37:29-38

Walling DE (1998) Use of ${ }^{137} \mathrm{Cs}$ and other fallout radionuclides in soil erosion investigations: progress, problems and prospects, use of $137 \mathrm{Cs}$ in the study of soil erosion and sedimentation rep. International Atomic Energy Agency, Vienna, IAEATECDOC 1028, pp 39-62.

Zhang J, Quine TA, Ni S, Ge F (2006) Stocks and dynamics of SOC in relation to soil redistribution by water and tillage erosion. Glob Change Biol 12(10):1834-1841

Zuazo VHD, Pleguezuelo CRR (2008) Soil-erosion and runoff prevention by plant covers. A review. In: Lichtfouse E, Navarrete M, Debaeke $\mathrm{P}$ et al (eds) Sustainable agriculture. Springer, Dordrecht, pp 785-811

Publisher's Note Springer Nature remains neutral with regard to jurisdictional claims in published maps and institutional affiliations. 